\title{
Entrepreneurship and Innovation in Obtaining Competitive Advantage in Non-Formal English Education Industry in Indonesia: A Model Proposition
}

\author{
Respati Wulandari \\ Management Department, BINUS Business School Undergraduate Program \\ Bina Nusantara University \\ Jakarta 11480, Indonesia \\ respati.wulandari@binus.edu \\ Correspondence: respati.wulandari@binus.edu
}

\begin{abstract}
This study aims to examine the effect of entrepreneurship on innovation in the non-formal English education industry geared towards achieving competitive advantage. Entrepreneurship is viewed through leadership, culture and entrepreneurship. Entrepreneurial leadership is a leadership approach that involves managerial and entrepreneurial capacity where this type of leadership is effective in running the business. So far, research on non-formal education in English through an entrepreneurial perspective and a strategic entrepreneur approach is very limited. Thus, a model proposal is constructed derived and drawn from the qualitative research that was conducted. This study will provide a review of entrepreneurship and innovation in non-formal education businesses in English.
\end{abstract}

Keywords: Strategic entrepreneurship; Non-formal English education industry; Jakarta

\section{INTRODUCTION}

The emergence of multinational schools and the change in Indonesian educational curricula have confused the business of the non-formal English education industry or so-called English classes. People's lifestyles, use of technology, the internet and purchasing power have influenced this business and are forcing them to adapt to this new global business environment. Some research has stated that in the face of an uncertain global business environment; the company must adopt the strategic entrepreneur approach as a means of obtaining a competitive advantage (McGrath \& MacMillan, 2000; Morris, Kuratko, Covin, 2008 in Ireland et al, 2009). Our research shows that the entrepreneurship of managers is proven to create innovation in their company. It is interesting to further study how "entrepreneurial strategies allow individuals to be innovative, creative and responsible for the decisions they make" (cited in Meyer \& Heppard, 2000, p.10 in Ireland et al, 2009) and how are managers more competitive in a very competitive market.

Indonesia has witnessed the escalation and reduction in the number of non-formal English lessons. Currently, there are 18,999 non-formal training courses in Indonesia comprising 70 types of training and 4,583 of these are non-formal English courses (Sulistyoningrum, 2015). They were 225 non-formal English courses in Jakarta, 119 in 2014, increase to 127 in 2015 (Infokursus.net) and decrease to 68 in 2016. In Jakarta, around 98,000 participants are actively learning English in English courses. with various market segments, from elementary school students to employees. The approximate turnover for this industry is IDR., 98 billion per term (per term consist of 3 months 
and 1 year consist of 3 terms). A survey conducted by Kompas (Litbang Kompas, 2012) showed that 58.3\% of students joined non-formal education classes to focus on lectures, including English. In the 2014 survey by Litbang Kompas, also showed that $97.6 \%$ of students consider the need to learn courses, including English, in a non-formal educational institution.

The teaching of English plays an important role in the progress of Indonesian students and employees in obtaining their competitiveness in study and work. The ASEAN 2015 community (Aring, 2015) stated that English proficiency is in the future employment-education agenda. English language in primary and secondary school is the ASEAN 2015 community recommendation to gain competitiveness (Aring, 2015). Many research papers have been collected and so far, to our knowledge, there is very little research on the non-formal education industry in English. Thus, we combine the phenomena of non-formal education in English in Jakarta in a strategic entrepreneurship approach.

Besides the programs provided by non-formal education in English, non-formal education is one of those avenues to provide quality basic education to all, as school alone could not provide such an element. of such quality basic education (Yasunaga in the UNESCO report, 2014). Non-formal education responds to the different and context-specific learning needs of children, youth and adults around the world and is characterized by a high degree of flexibility and openness to innovation and change in its organization, as well as in its delivery methods and pedagogy. Non-formal education in English itself has come to introduce and develop innovations to improve their performance to meet the needs of the market and society. It is important to increase the recognition and validation of non-formal learning in the business context. This will help managers of non-formal English courses to improve their leadership in doing their business.

We are interested in revealing the non-formal English education industry or the competitiveness of English courses due to its importance as a role of non-formal education in developing human capacities, improving social cohesion and create a future responsible citizen (Yasunaga, 2014). Thus, we conducted an exploratory study to reveal this industry and grasp the situation and the problems faced by non-formal education in English in running their business. Our research reveals the importance of the implementation of entrepreneurial factors as a determinant of innovation in obtaining a competitive advantage for this industry in the competitive environment.

This industry has existed for over 40 years in Indonesia. Many actors accompany the demand for the English language in global need. Therefore, the rivalry between the institutions is fierce. When English classes first arrived in Jakarta, the majority of participants were students and employees. The programs were also designed to meet the needs of students and employees. From the year 2000, primary and secondary school became the target clientele of several players, especially new entrants. This is due to the need for English study programs in primary and secondary schools and students have to adapt to this demand. Learn English for specific purposes for employees, such as hospitality and tourism, business English, TOEFL, IELTS, English for sworn translator, finance and corporate learning, has been an interesting product to offer to gamers. With the huge demand that has been experienced by students and employees, this situation is seized by several players as an opportunity to seize the market. This industry changes from time to time and players need to innovate their product and business model to adapt to market trends and demand.

Our exploratory study reveals unique opportunities and challenges faced by managers/ leaders. This situation allows them to innovate. As the demand for English literacy increases and many non-formal educations in English occur, several issues are identified in the management of non-formal education in English:

1. Tough competition

2. The technology and development of the Internet has become commonplace for adults.

3. People tend to think that learning English will only take 3 months and that they will be able to speak fluently. Thus, many non-formal educations in English appear in a very short time and have not been able to survive.

4. The student's school schedule.

5. Manager's inability to manage the business.

Faced with the changes and challenges happening in Jakarta, non-formal education in English in Jakarta offers various innovations to meet the market demand and seize the market. Innovations themselves initiated by the leader / manager of each English course or center. Innovations come with many categories, product category such as learning method, technology application, corporate learning, social club activities; Category of service such as 
providing internships and distribution of work to industry, workshop and seminar for staff; Category of business model such as partnership with an external party. These types of innovations are aimed at gaining a competitive advantage. However, the president of the IECTA (Indonesian English Course Teachers Association) said that not all those responsible for non-formal education in English could develop innovation to gain a competitive advantage (interview of September 5, 2015). He also said that many managers have limited entrepreneurial capacity to develop the business, which is very important to improve the performance of the business. This situation indicates that not all English schools or courses could provide and meet the public demand for English language learning.

There are various studies on organizational innovation, but most of them are related to the manufacturing industry, the health sector and even the music industry (Iplik et al, 2014). Few researches has been used on school innovation, so the main objective of this research is to discuss strategic innovation in non-formal education in English in Jakarta from a strategic entrepreneurship perspective.

Since innovation is an important part of business growth, we therefore bring a strategic entrepreneurship approach to conducting this research. Strategic entrepreneurship is a new concept based on the combination of entrepreneurship and strategic management (Ireland et al, 2003). It combines a behavior that seeks opportunities and a competitive advantage (Ireland and Web, 2007). Several studies concerning leadership, culture, mindset, innovation and competitive advantage from a strategic and entrepreneurial perspective were reviewed. At this point, there is an indication of continued efforts to develop strategic entrepreneurship in various types of organizations and businesses. On the other hand, there is a lack of rigor in previous research studies and ambiguous results regarding the application and determination of the dimensions of strategic entrepreneurship, especially no implementation in the construction industry. non-formal education in English. Given this situation, it is of theoretical and practical relevance to research the implementation and impact of entrepreneurial factors and innovation in obtaining a competitive advantage.

Our article goes as follows. First, we discuss a brief exploratory study on this company. Next, the earlier model of strategic entrepreneurship from Ireland et al (2003) will be examined in more detail in relation to the business context, and a new model is provided. The article ends with a summary as well as suggestions for future research.

\section{METHODS}

We used a qualitative study to conduct this research. There are 20 English courses from different brands that were observed, and managers were interviewed. This exploration was conducted for about 8 months in 2016. Twenty English courses are a sample of the entire population of Jakarta, which serves as a benchmark and research studies. Their interview has been analyzed and a coding is presented to fulfill the strategic entrepreneurial dimensions. The indicators are provided as an extension of the theories.

\section{Literature Review and Analysis}

\section{Strategic Entrepreneurship}

According to Ireland et al (2003), strategic entrepreneurship is the means for a company to seek superior performance through simultaneous activities of seeking opportunities and advantages. By combining these two dimensions, companies attempt to create wealth by harnessing the current competitive advantage, and if companies set the stage for future performance by identifying ideas, companies will create subsequent benefits (Ireland and Webb, 2007). It is not easy to develop both dimensions as each requires huge different organizational capacities. But, by applying this strategy, simultaneously seeking both advantages and opportunities, the company can survive in today's global economic arena or in dynamic changes (Hitt et al., 2001; Ireland \& Hitt, 1999).

For small businesses like the English course, the strategic approach offers several unique advantages and disadvantages (Szilagyi, 1984). On the benefit side, English lessons may not present the complexity and detail that large companies face in their strategic planner. In fact, small businesses can be seen as straightforward in their strategic business unit. Other advantages are their limited product, market served, services, limited number of options, and small resource base. On the downside, first of all, the management team is small, sometimes just one person in a company. The entrepreneur or manager may have run the business based on instinct or point of view and sees little use in a formalized process. Second, the data and information to prepare for internal and external analysis may be limited. Third, employee resistance to change can develop. Another problem can be limited resources. 
Here is the prior model of Ireland et al. (2003) which will be further examined according to the industry.

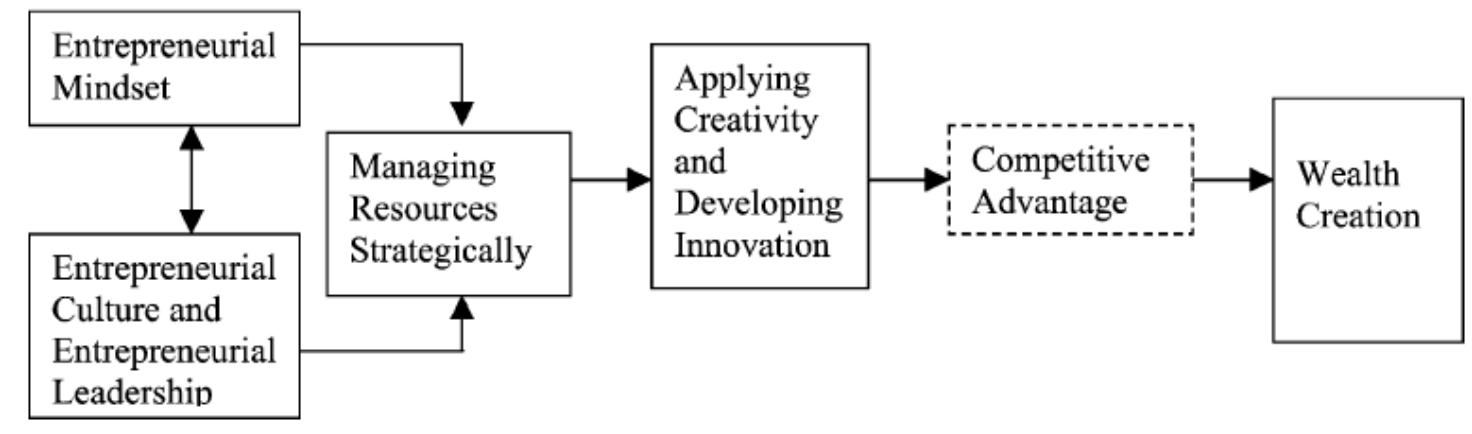

Figure 1: Model of Wealth Creation by Ireland et al. (2003)

(Source: Ireland et al, 2003)

\section{Entrepreneurial Leadership}

Entrepreneurial leadership is the ability to influence others and manage resources strategically in order to achieve seeking behavior and the pursuit of profit opportunities (Covin \& Slevin, 2002; Ireland \& Hitt, 1999; Rowe, 2001). According to Lee and Venkataraman (2006) in Hejazi et al (2012), entrepreneurial leadership is known as a dynamic process for presenting the vision, creating engagement among followers and accepting the risk in the face of a leader's vision. Thus, entrepreneurial leadership includes all the capacities necessary to create value for the manager to see the objectives of the company. Entrepreneurial leadership is also seen as a basis for competitive advantage.

Based on the interview with managers, here are some entrepreneurial leadership factors that occur: communicative; encouraging; favorable; business knowledge; Creative; ability to analyze environmental threat; ability to see the opportunity; risk taker. Therefore, the entrepreneurial leadership variable is interesting to explore, and research indicators need to be developed.

Entrepreneurial leadership is the ability to influence others and to manage resources strategically in order to acquire behaviors that seek opportunities and benefits (Covin \& Slevin, 2002; Ireland \& Hitt, 1999; Rowe, 2001). It is also one of the newer terms combining the elements of leadership, strategy and entrepreneurship in running a high growth business. It is characterized by Covin and Slevin (2002) in six imperatives. We review the 6 imperatives in indicators according to our context, namely non-formal education in business English or English lessons.

1. Nurture an entrepreneurial capacity

Creative in the development of the institution's resources; placing human resources and a wide range of important things in the right place in the institution; decision maker; confident to influence staff/ team to innovate; able to understand the work needs of the team/staff; motivate the team / staff.

2. Protect innovations threatening the current economic model.

Openly communicate information about innovation that could threaten the current business when it has good prospects; predict future problems and crises affecting English course business; able to illustrate the phenomenon in the future to the team.

3. Make sense of opportunities

Pursue the opportunity to develop a business English course; ready to invest in a risky project; develop an information system to explore environmental changes that could affect businesses; held regular meetings to obtain feedback on innovation development and business activities.

4. Question the dominant logic.

Conceptualize the activity of the course by evaluating its position in relation to its competitors; assess the decision regarding the allocation of resources in the institution.

The two other imperatives, which are to revisit "deceptively simple questions" and to link entrepreneurship and strategic management were not mentioned during our interview with managers, so we did not review them. 


\section{Entrepreneurial Culture}

Dess and Picken (1999) stated that organizational culture is a system of shared values and beliefs that shape the structural arrangements of the company and the actions of its members to produce norms of behavior. It also affects the provision of guidance and support among employees. The commitment to seek out opportunities and advantageous behaviors requires an effective entrepreneurial culture. According to Ireland et al (2003), this culture is a culture in which new ideas and creativity are expected, risk taking is encouraged, failure is tolerated, learning is encouraged, product, process and innovation innovations. administrative structures are defended, and continuous changes are seen as a vector of opportunity. By applying them, the company can exploit opportunities with sustainable competitive advantage (McGrath \& McMillan, 2000).

Based on the interview with managers, here are some entrepreneurial culture factors that occur: encourage and wait for the team / staff's investment in the English language course program; welcome feedback from parents; encourage individuality; accept mistakes and errors; do everything possible to make sure the team / staff know they are important; open to staff / team; conveying creative ideas to a business opportunity; risk taker; positive attitude; innovative; entrepreneurship; cost awareness. Therefore, the entrepreneurial culture variable is interesting to explore, and research indicators need to be developed.

We review the definition of entrepreneurial culture by Ireland et al (2003) and define indicators according to the business English course and interviews with managers.

1. New ideas and creativity are expected

Accept new ideas from team/staff in pursuing business opportunity

2. Risk taking is encouraged.

Encourage risk taking in achieving business opportunity

3. Failure is tolerated.

Tolerate to failure of opportunity taking by team/staff in the institution

4. Learning is promoted.

Encourage learning regarding product, business process, and innovation

5. View environmental changes.

See environmental changes as business opportunity in English course.

We give an additional dimension to this context; Influence of the business owner. In this context, the manager is not a business owner. The business owner, according to our interview with managers, has a strong influence in decision-making. The manager must report and discuss all new activities and decisions emanating from the team or from the manager himself. Sometimes the business owner either agrees or disagrees with the new program or business model. It is often experienced by managers that they have to express their opinions to owners. Sometimes disputes arise between them. Most business owners are not prepared to take on risky projects or innovative programs. Instead, they just follow the head office schedule and rules.

In some cases, we have captured, managers have rejected our interview due to the order of the business owner or resistance from management. In the event of commercial activity, managers must obey any decisions or rules that have been made by their owners. It often happens that the behaviors of managers mimic their business owner. Therefore, the culture of the business owner in the context of entrepreneurial culture needs to be further examined in this research.

Entrepreneurial culture is a culture where teams are invited and encouraged to give ideas to develop the business and to show tolerance in the event of failure. Teams are always invited to see and recognize opportunities, are encouraged to always learn from failure and this culture is a manifestation of the birth of innovation in the company. This culture can be created if the leader and the team are open to the introduction of opportunity, acceptance of risk and tolerance for failure. Compared to the institution of non-formal education in English, this culture can be created from the existing system, with good flexibility imposed by the owner, or on the initiative of the managers themselves.

\section{Entrepreneurial Mindset}

It is important to have an entrepreneurial mindset to successfully engage in strategic entrepreneurship. It is important for individual entrepreneurs as well as for managers and employees to start businesses by thinking and acting in an entrepreneurial manner (Covin \& Slevin, 2002). Based on the statement by McGrath and MacMillan (2000), the entrepreneurial mindset is a way of thinking about business that focuses on and captures the benefits of uncertainty. Thus, entrepreneurship contributes to competitive advantage (Miles, Heppard, Miles \& Snow, 2002). This state of mind can promote flexibility, creativity, continuous innovation and renewal of the individual. 
Based on the interview with managers, here are some entrepreneurship factors that occur: pro-active; maintain superior quality; see challenges and competition as an opportunity; act like a business owner. Therefore, the entrepreneurial variable is worth considering further and research indicators need to be developed.

We review the components of an entrepreneurial mindset based on Ireland et al (2003). Indicators are provided depending on the context.

1. Recognizing entrepreneurial opportunities.

Identify business opportunities to develop the institution; Increase resources (product, service) for business development.

2. Entrepreneurial alertness.

Stimulate the development of products / services become more valuable to English c c o u $r \mathrm{~s} e$ 's consumer; Passionate in the pursuit of business opportunities; Discipline in the pursuit of the most promising business opportunities; Consistent focus on program execution; Committed to support the team / staff in identifying and pursuing business opportunities.

3. Real option logic

Analyzing the uncertainty of future business.

4. Entrepreneurial framework.

Establish business goals by exploiting the entrepreneurial opportunity; Build a list of opportunities to develop business; Determine the right time to launch business strategy in business development.

An entrepreneurial mindset is a state of mind that is ingrained in a person's mind to recognize that there are opportunities where others don't see them as an opportunity. This mindset helps businesses in very dynamic and uncertain situations to gain the benefits of the situation. An entrepreneurial mindset factor that often appears during an interview with the manager makes these variables important to explore in more depth.

\section{Innovation}

Innovation is linked to the success of the company in the industrial sector and the service sector (Kluge, Meffert \& Stein, 2000). Effective innovations create value for the customer (Mizik \& Jacobson, 2003). In 1997, Christensen stated that there are at least two types of innovation that companies can engage in, which is disruptive and sustainable innovation. The one that can contribute to the competitive advantage of the company is the maintenance of innovation. But, on the other hand, radical or disruptive innovation arises from identifying and exploiting opportunities through new combinations of resources to create new capabilities in which it can lead to competitive advantage. Business leaders engage in both disruptive and sustainable innovation.

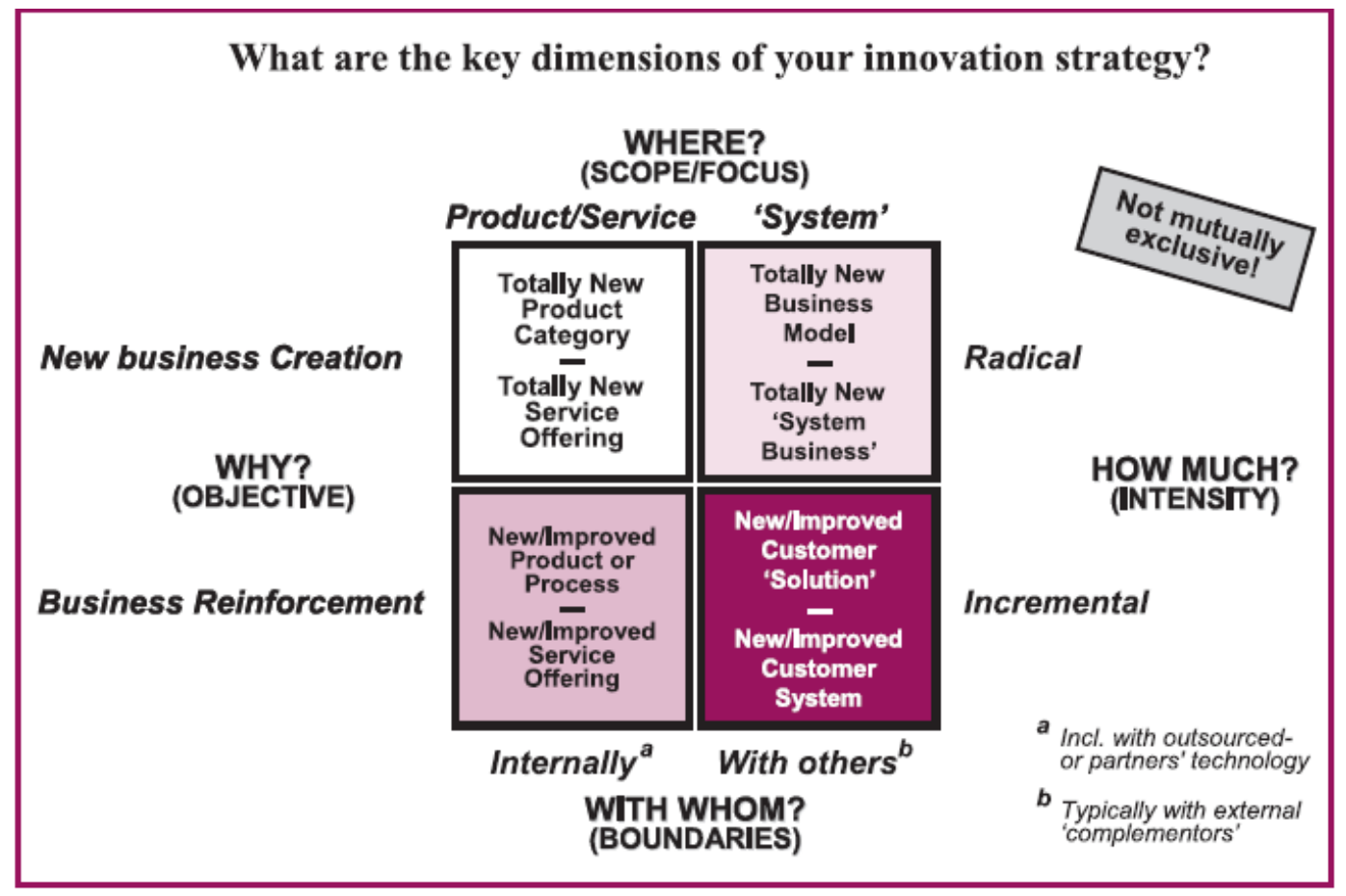

Figure 2: Innovation Strategy by Deschamp, 2005

(Source: Deschamps, 2005) 
Our research reveals some innovations brought by English courses and can be classified into several categories. Product categories such as learning method, technology application, corporate learning, social club activities; Categories of services such as the provision of internships and jobs in industrial distribution, training and seminars for staff; Category of business models such as partnerships with external parties, such as formal schools, universities, businesses, modern restaurant or convenience store and bank. These innovations aim to gain a competitive advantage.

Based on our interview and observation, the key dimension of innovation strategy by Deschamp (2005) in English courses can be examined as below:

\section{Totally new product category or service offering}

This is called a breakthrough in the business. Creating a whole new category of products or services is a strategic move requiring the full support of top management. It is entering a whole new market territory. Breakthrough cannot happen without supportive leadership from top management.

The indicators for this dimension are: Make the products / services that differ from today's business; Application of technology in teaching and learning English.

\section{Totally new business model or "system-business"}

This type of innovation is a powerful way to improve a current business. In business model innovation, the company notably involves external partners. The indicators for this dimension are: Cooperate with other parties to develop business courses; Create a model / new business system different from the current one; Creation of events or courses of outdoor activities; Create another business unit to expand the business.

\section{New/improved "customer solution" or customer system}

This innovation could be achieved by making an innovation partnership. It can improve a business by moving the business from selling products to providing a customer solution. The indicators for this dimension are: Course fee payment system updated / improved; Updated / improved online course system; Updating / improving the decor or facilities of the building for the convenience of consumers; Out of class lessons.

\section{New/improved product, process or service offering}

This latter type of innovation is the most commonly used in business. Obtaining an additional product line or service in the eyes of customers is the primary goal of most innovation efforts, in terms of product line, quality, performance, functionality or cost.

The indicators for this dimension are: Updated / upgraded curriculum; updated / upgraded the process or method of learning; Updated / upgraded administrative services, Updated/upgraded book design.

In addition to the key dimension of strategic innovation (Deschamp, 2005), we add an additional dimension to that implemented by English courses, which is Marketing Innovation. Marketing innovation consists of the evolution of the marketing mix and the improvement of the quality of service. Marketing innovation aims to seek potential markets and respond to the quality of service according to the target market (Johne, 1999 in Iplik et al, 2014).

The indicators for this dimension are: Held a roadshow promotion from school to school; Follow the exhibition at the mall; Creating advertising in mass media; The worth of mouth promotion; Give free trial course.

Various types of innovations have been made by the industry of non-formal English education to gain competitive advantage. In developing innovation, leaders are required to have the capability as entrepreneur and manager. Thus the leadership qualities such as entrepreneurship, entrepreneurial mindset and an entrepreneurial culture can be inferred to have a role in the development of innovation in this business.

\section{Competitive advantage}

Arguments advanced by recent research suggest that the most important competitive advantages are those resources that are more valuable, imperfectly imitated, scarce and non-substitutable than those held by competitors (Gove, Sirmon \& Hitt, 2003). He also explained that competitive advantage involves the ability to meet customer needs more effectively than their competitors (Papulova \& Papulova, 2006). It is therefore achieved if and when real value is added and experienced by customers. Important elements for adding value are (Thompson, 1997) a commitment to quality, a quick reaction to competitive opportunities and threats, and understanding and closeness to customers. Small organizations that understand their customers could create a competitive advantage and benefit from a higher process and their loyalty. 
Based on our scoping study, here are some competitive advantages in each of the English course leaders who were interviewed: focus on conversation; Emphasize grammar; Concept of arranged simulation; Has a virtual account for students and parents; Personalized learning method; Toefl simulation test facility; Qualified teachers with an excellent training program; Computer based learning; Free course schedule; Provide national and international certificate.

Interviews were also conducted with participants in the English courses. Based on our interview with participants from primary school to employees, we obtained a certain competitive advantage or uniqueness of each location such as: Well-known institution brand; Affordable course fees; More emphasis on grammar; Put more emphasis on daily conversation; A good place for the communion of young people; Located in the shopping center or near residents' accommodation; Provide English for Business (English for Special Purpose) program; Have a good program and a fun learning. Based on the various reasons raised by the participants, especially the primary and secondary participants, they said they were joining the English class due to parents' order and recommendations from friends or relatives. Overall, they have a similar product, but the participants have their own selection criteria.

Cost leadership is no longer suitable for this company because according to our research, no institution could maintain its quality and its employees with a small budget. Based on this fact, we replace cost leadership with a hybrid strategy (Al-Zoubi, 2012). It's the combination of cost leadership and differentiation that works best for this business. Abou-Moghli et al (2012) explain the dimensions of competitive advantage in the banking sector in Jordan, which are: time, quality, cost and flexibility. These dimensions have been discussed further and the indicators are provided as follows:

1. Hybrid strategy: Cost leadership and differentiation.

The institution builds confidence that the best quality and low cost must support each other; The institution recognizes the needs and expectations of changing and evolving consumers; Institution committed to quality products and innovative services.

2. Time

Institutions offer a shorter course.

3. Quality

Provides international certified teachers: Provides national standard certificate; Provides international standard certificate; Provides a standard international curriculum; Provides their consumers with comfort and modern room / building.

4. Flexibility

The establishment provides the appropriate selection of the course schedule according to the activity of the consumers; offers a choice of course types (private/semi-private/joint) depending on the needs of consumers; Provides curriculum options based on consumer needs.

According to Mintzberg (Robbins \& Stuart-Kotze, 1990 in Papulova \& Papulova, 2006), business strategy is about competitive advantage and can follow one of three modes: planning, entrepreneurship and adaptive. Mode displays an entrepreneurial approach of a strong leader by attracting private judgment and experience to build a portrait based on the instinct of user companies. With these explanations, the role of leader or manager in an organization, or more precisely in the non-formal education industry in English, the leader can maximize his influence and his role in obtaining a competitive advantage by using an entrepreneurial perspective. 


\section{RESULT AND DISCUSSION}

\section{Model Proposition}

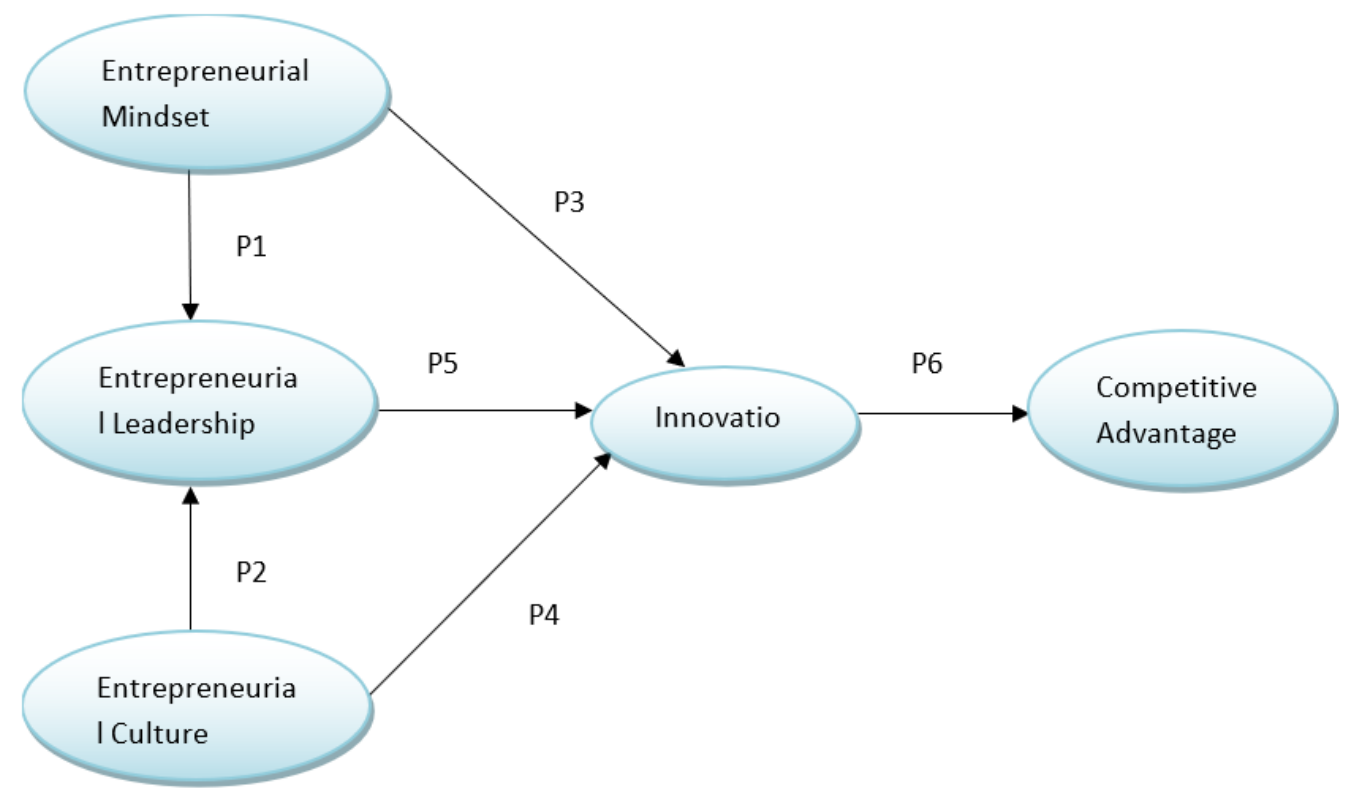

Figure 3: Model Proposition Entrepreneurial Mindset, Culture, Leadership towards Innovation and Competitive Advantage (Source: Wulandari, R, 2016)

\section{Entrepreneurial Mindset to Entrepreneurial Leadership and Innovation}

There are several studies that indirectly support the entrepreneurial mindset with entrepreneurial leadership. There is no exam regarding the entrepreneurship dimension and its effect on this English course. The dimensions that already existed in previous studies vary between one and the other.

Five studies were selected to assess the entrepreneurial mindset related to research and two studies related to leadership. A study by Dover and Dierk (2013) the Index Manager, Entrepreneur Leader (MEL) describes that the combination of managerial and entrepreneurial skills needed to determine business success. However, this study does not contain the dimensions of mindset tested in this research. However, the study was not strong enough. The questions in this research provide an in-depth understanding of how the dimensions of developing an entrepreneurial mindset and its effect on entrepreneurial leadership in non-formal English education. Other research by Roomi and Harrison (2011) mentions the positive relationship between an entrepreneurial mindset and leadership. In his research, M.J. Scheepers (2008) mentions that the entrepreneurial mindset supports entrepreneurial leadership.

Interviews with several managers indicate factors of entrepreneurial mindset and entrepreneurial leadership in running a business. Based on previous research; it can be concluded that the entrepreneurial mindset affects entrepreneurial leadership. The following proposal is proposed:

Proposition 1: The strength of the entrepreneurial leader / manager mindset is positively linked to entrepreneurial leadership.

Here we are offering a unique statement. Manager, as an individual or ordinary staff, ideally has an entrepreneurial mindset to develop innovation in the world. Thus, without being a manager, he can contribute to the development and creation of innovation. The next proposition related to entrepreneurship is:

Proposition 3: The strength of entrepreneurial mindset is positively linked to innovation in the non-formal education sector.

\section{Entrepreneurial Culture to Entrepreneurial Leadership and Innovation}

To lead entrepreneurial leadership, entrepreneurial culture is an important element to boost the performance of entrepreneurial leadership in the organization (Ireland et al, 2003). Thus, the entrepreneurial culture fosters and supports the continuous search for entrepreneurial opportunities that can be exploited with sustainable competitive advantages (McGrath \& MacMillan, 2000). Leaders are responsible for developing and maintaining an entrepreneurial culture. 
There is a number of researches that indicates a relationship between corporate culture and leadership. A study by Alnasseri et al (2013) shows the relationship between corporate culture and leadership style among construction clients in the Middle East. The study was conducted only in the construction sector in the Middle East. Al Mazrouei et al. (2015) have shown in their case studies that corporate culture has an impact on leadership style. The study was conducted in the United Arab Emirates. There is also a study by Ng'anga and Nyongesa (2012) on the impact of corporate culture on the performance of educational institutions. These studies are not carried out in the perspective of an entrepreneurial culture, as well as in its dimensions. However, the results are still associated with this research. There are two studies related to the culture of entrepreneurship and leadership. Zouhayer (2013) uses a different dimension in the research that takes place in the Tunisian company and it shows that it takes a great influence in leadership to change the culture.

We offer a unique proposition that is different from other previous research. Numerous researches have stated that the leader will affect the corporate culture. But we reverse this assertion. We have discovered that the nature of this industry is different from others. The culture of the manager and the owner affects his leadership. Thus, the following proposition is proposed:

Proposition 2: The strength of the leader / manager entrepreneurial culture is positively linked to entrepreneurial leadership.

Similar to Proposition 3, we propose Proposition 4 with respect to the nature of this industry. Each individual, manager or employee, is by nature endowed with an entrepreneurial culture. Keep this conviction, he or she can contribute to the development and creation of innovation without being a manager. The next proposition related to entrepreneurial culture is:

Proposition 4: The strength of entrepreneurial culture is positively linked to innovation in the non-formal English education sector.

\section{Entrepreneurial Leadership to Innovation}

Entrepreneurial mindset and entrepreneurial culture support the performance of entrepreneurial leadership and innovation. It aims to obtain a sustainable competitive advantage of the company. Capturing the non-formal English education industry to cope with changes and challenges, the business needs the type of manager who has an entrepreneurial perspective and a strategic perspective in running the business. Entrepreneurial leadership is a type of leadership required to deal with changes, crises and challenges of the current organizational framework (Gupta, MacMillan \& Surie, 2004). This type of leadership allows the leader to guide his organization successfully and solve the problem of the organization through different stages of growth and development of the organization (Chen, 2007; Swiercz \& Lydon, 2002). It has a great influence on the competence of the leader to recognize new opportunities concerning the improvement of the performance of the organization (Chen, 2007; Okudan \& Rzasa, 2006; Gupta et al., 2004). Due to the positive impact resulting from the application of entrepreneurial leadership, researchers have led this type of leadership to be implemented in the educational aspect, especially in school performance (Xaba \& Malindi, 2010; Berglund \& Holmgren, 2006; Collin, Hannon \& Smith, 2004; Eyal \& Kark, 2004; Eyal and Inbar, 2004 in Park, 2012). According to Park (2012), the focus has been on entrepreneurial leadership to create change and innovation in a school-friendly environment. This research indicates that entrepreneurial leadership contributes to a positive impact on school innovation. However, there is very little research that has been done in non-formal English education.

Several previous research regarding the measurement of entrepreneurial leadership had been conducted in schools, small and medium-sized enterprises, and enterprises, but there is a lack of rigor in previous research studies and ambiguous results regarding the measurement of dimensions of business. entrepreneurship. Qualitative research was conducted with directors of vocational schools in Malang, Indonesia (Suyitno et al, 2014). The result indicates that entrepreneurial leadership performs well in vocational schools and they mentioned some characteristics of entrepreneurial leadership. Each research shows different dimensions of entrepreneurial leadership. Research by Pihie, Asimiran and Bagheri (2014) shows that entrepreneurial leadership has an impact on school innovation. But this research was conducted by measuring the entrepreneurial leadership practices of principals and school innovation from the perspective of the teacher, not the principal himself. There is other conceptual research and literature reviews that show the positive link between leadership and innovation (Von Stamm, 2009; Deschamps, 2005; Kuratko, 2007). At a glance, it appeared that most of the studies reported a positive impact of leadership and innovation which severely limited the validity of the result. This is the opportunity for us to conduct this study on non-formal education in English through the perspective of leaders / managers. Thus, the following proposition is proposed: 
Proposition 5: The strength of the entrepreneurial leadership of the leader / manager is positively linked to the development of innovation in the non-formal education sector in English.

\section{Innovation to Competitive Advantage}

The research of Mary M. Crossan and Marina Apaydin (2010) is the basis of this proposition. We are aware that a lot of research has been done to study strategic innovation to gain competitive advantage in many industries. But, so far, no research has been conducted to investigate innovation and competitive advantage in the non-formal English education sector. We believe that our study will contribute to research in strategic management. Thus, the following proposition is proposed:

Proposition 6: The uniqueness of innovation is positively related to competitive advantage in the non-formal education sector in English.

\section{CONCLUSION}

Our article brings 2 aspects. First, this research shows and reveals a footage industry that never existed and is made up of non-formal English education businesses. A qualitative study was conducted to understand the state and problems of this business. Finally, the subject of the strategic entrepreneur has been an interesting subject to review and add for 15 years. Thus, our article uses a strategic entrepreneur approach as the basis for gaining competitive advantage in a dynamic environment. Entrepreneurial behavior has been proven to occur in the way managers run English lessons. The leadership, culture and mindset of entrepreneurship are essential factors as a path to innovation. This article helps define the dimensions and strategic indicators of entrepreneurship.

\section{Future research}

This research requires a statistical study in addition to our qualitative study. Therefore, the dimension and the indicators could be deepened as an extension of our study.

\section{REFERENCES}

Al Mazrouei, Hanan, Pech, and Richard. J. (2015). The expatriate as company leader in the UAE: Cultural adaptation. Emerald Insight. Vol 36, No.1. pp. 33-40

Alnasseri, N., Osborne, and Steel, G. (2013). Organizational culture, leadership style and effectiveness: A case study of Middle Eastern construction clients. In: Smith, S.D and Ahiaga-Dagbui, D.D (Eds) Procs $29^{\text {th }}$ Annual Conference, 2-4 September 2013, Association of Researchers in Construction Management, 393-403.

Aring, M. (2015). ASEAN Economic Community 2015: Enhancing competitiveness and employability through skill development. ILO Asia-Pacific Working Paper Series.

Al-Zoubi, M.R. (2012). Leadership competencies and competitive advantage "Empirical study on Jordan telecommunication. European Journal of Business and Management, Vol 4. No. 7

Astuti, PP. (2012). “Ramai-ramai Les Pelajaran.” Litbang Kompas. Jumat, 7 Desember, 2012.

Chen, M.H. (2007). Entrepreneurial leadership and new ventures: Creativity on entrepreneurial teams. Creativity and Innovation Management, 16(3):239-249.

Christensen, C. M. (1997). The innovator's dilemma. Boston: Harvard Business School Press.

Crossan, M.M and Apaydin, M. (2010). A multi-dimensional framework of organizational innovation: A systematic review of the literature. Journal of Management studies. 47:6

Covin, J. G., and Slevin, D. P. (2002) The entrepreneurial imperatives of strategic leadership. In M. A. Hitt, R. D. Ireland, S. M. Camp, \& D. L. Sexton (Eds.), Strategic entrepreneurship: Creating a new mindset: 309-327. Oxford: Blackwell Publishers.

Deschamps, J.P. (2005). Strategy and Leadership. Emerald Insight. Vol.33: 31-38 
Dess, G. G., \& Picken, J. C. (1999). Beyond productivity: How leading companies achieve superior performance by leveraging their human capital. New York: AMACOM.

Dover, P.A. and Dierk, U. (2013). The Ambidextrous Organization: Integrating Manajers, Entrepreneurs and Leaders, Journal of Business Strategy, Vol.31, no 5, pp 49-58. Economist Intelligence Unit (EIU). (2012). Skilled labour shortfalls in Indonesia, the Philippines, Thailand and Vietnam: A custom research report for the British Council (London). Available at: https://ihe.britishcouncil.org/sites/default/files/ Skilled_Labour_Shortfalls_Report.pdf [9 Dec. 2014].

Gupta, V., Macmillan, I.C \& Surie, G. (2004). Entrepreneurial leadership: Developing and measuring a cross-cultural construct. Journal of Business Venturing, 19(2):241-260. http://dx.doi.org/10.1016/S08839026(03)00040-5

Hejazi, S.A.M., Maleki, M.M., Naeiji, M.J. (2012). Designing a scale for measuring entrepreneurial leadership in SMEs. International Conference on Economics Marketing and Management IPEDR vol 28 (2012). P 71-77

Hitt, M. A., Ireland, R. D., Camp, S. M., \& Sexton, D. L. (2001). Strategic entrepreneurship: Entrepreneurial strategies for wealth creation. Strategic Management Journal, 22(Special Issue): 479-491.

Iplik, F.N., Topsakal, Y., Gogan, O. (2014). Strategic innovation: an empirical on hotel firms operating in Antalya region. Advances in Hospitality and Tourism Research, 2(1): 16-29

Ireland, R. D., \& Hitt, M. A. (1999). Achieving and maintaining strategic competitiveness in the $21^{\text {st }}$ century: The role of strategic leadership. Academy of Management Executive, 13(1): 43-57

Ireland, R.D., Hitt, M. A., \& Sirmon, D.G. (2003). A model of strategic entrepreneurship: The Construct and its dimensions. Journal of Management, 29;963-989

Ireland R.D. and Webb, J.W. (2007). Strategic entrepreneurship: creating competitive advantage through streams of innovation. Business Horizons 50: 49-59.

Ireland, R.D., Covin, JG., and Kuratko, D.F (2009). Conceptualizing corporate entrepreneurship strategy. Entrepreneurship Theory and Practice. 1042-2587.

Kluge, J., Meffert, J., and Stein, L. (2000). The German road to innovation. The McKinsey Quarterly, 2: 99-105.

Kuratko, D.F. (2007). Entrepreneurial leadership in the 21 st century. Journal of Leadership and Organizational Studies, 13(4), 1-11.

Mcgrath, R. M., and Macmillan, I. C. (2000). The entrepreneurial mindset. Boston: Harvard Business School Press.

Miles, G., Heppard, K. A., Miles, R. E., and Snow, C. C. (2000). Entrepreneurial strategies: The critical role of top Management. In G. D. Meyer \& K. A. Heppard (Eds.), Entrepreneurship as strategy: Competing on the entrepreneurial edge: 101-114. Thousand Oaks, CA: Sage Publications.

Mizik, N., and Jacobson, R. (2003). Trading off between value creation and value appropriation: The financial implications of shifts in strategic emphasis. Journal of Marketing, 67: 63-76.

Ng'anga, M.J and Nyongesa, W.J. (2012). The impact of organizational culture on performance of educational institutions. International Journal of Business and Social Science. Vol. 3 no.8.

Okudan, Ge and Rzasa, Se (2006). A project-based approach to entrepreneurial leadership education. Technovation, 26(2):195-210. http://dx.doi.org/10.1016/j.technovation.2004.10.012

Papulova, E and Papulova, Z. (2006). Competitive strategy and competitive advantages of small and midsized manufacturing enterprises in Slovakia. E-Leader, Slovakia.

Park, J.H (2012). The effects of principal's leadership style on support for innovation: evidence from Korean vocational high school change. Asia Pacific Education Review, 13(1):89-102. DOI: 10.1007/s12564011-9182-9

Pihie, Z.A., Asimiran, S. and Bagheri, A. (2014). Entrepreneurial leadership practices and school innovativeness. South African Journal of Education; 2014; 34(1)

Rowe, W. G. (2001). Creating wealth in organizations: The role of strategic leadership. Academy of Management 
Executive, 15(1): 81-94.

Scheepers, M.J. (2008). Entrepreneurial mindset of information and communication technology firms. Peer Reviewed Article. Vol. 10 (4) December.

Sulistyoningrum, Y. (2015). "Kursus Bahasa Inggris: Saat ini tersedia 4.583 tempat belajar." Industri Business. Com. Jum'at, 06/11/2015 12:20 WIB. Available at: http://industri.bisnis.com/read/20151106/12/489568/ kursus-bahasa-Inggris-saat-ini-tersedia-4.583-tempat-belajar

Suyitno, S.A, Arifin, I, and Ulfatin, N. (2014). Entrepreneurial leadership of vocational schools principal in Indonesia. International Journal of Learning \& Development. Vol.4, no.1

Swiercz, P.M and Lydon, S.R. (2002). Entrepreneurial leadership in high-tech firms: A field study. Leadership and Organization Development Journal, 23(7):380-386. DOI: 10.1108/01437730210445810

Szilagyi, A.D. (1984). Management and Performance. Scott, Foresman and Company, Glenview, Illinois.

Thompson, J.L. (1997). Strategic Management. Awareness and Change. International Thomson Business Press. London

Von Stamm, B. (2009). Leadership for innovation: what you can do to create a culture conducive to innovation. Strategic Direction, vol 25 lss 6 pp.13-15

Yasunaga, M. (2014). Non-formal education as a means to meet learning needs of out-of school children and adolescents. UNESCO. 2 May 2014

Zouhayer, M. (2013). Entrepreneurial culture, profile of the leader and entrepreneurial orientation: Empirical application in the case of Tunisian companies. International Journal of Managing Value and Supply Chains. Vol. 4 No.4 